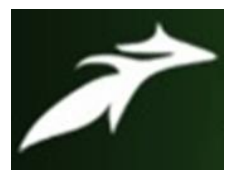

D.Srikanth et al, International Journal of Advances in Agricultural Science and Technology,

Vol.8 Issue.9, September-2021, pg. 126-135

ISSN: 2348-1358

Impact Factor: 6.057

NAAS Rating: 3.77

\title{
UTILIZATION OF MASS MEDIA BY THE FARMERS IN MAHBUBNAGAR DISTRICT OF TELANGANA
}

\author{
D.Srikanth ${ }^{1}$; Jahanara ${ }^{2}$; Dipak Kumar Bose ${ }^{3}$ \\ ${ }^{1}$ Research Scholar, Department of Agricultural Extension and Communication, SHUATS, Allahabad, Uttar Pradesh, India \\ ${ }^{2}$ Professor and Head, Department of Agricultural Extension and Communication, SHUATS, Allahabad, Uttar Pradesh, India \\ ${ }^{3}$ Associate Professor, Department of Agricultural Extension and Communication, SHUATS, Allahabad, Uttar Pradesh, India
}

DOI: 10.47856/ijaast.2021.v08i9.014

\begin{abstract}
The agricultural growth considerably depends on the communication of information and knowledge which is transferred among farmers the mass media plays an important role in dissemination of agricultural information, the mass media contributes in spreading of information and enables remote areas farmers to make decision about farming activities (Chhachhar, 2012). Mahabubnagar district of Telangana state was selected purposively based on the maximum farmers' availability. Descriptive research design was used for the present study. A total of 120 respondents were selected purposively as a sample for the present investigation. The data was collected by using pre-tested schedule and analyzed using appropriate statistical tools chi-square test was applied to find out the relationship between the utilization of mass media by farmers with independent variables. It was concluded that the socio-economic status of the respondents constitute medium level. It was observed that majority of the respondents belonged to the high level of Utilization of mass media. There was a positive relationship between utilization of mass media with independent variables like Age, family size, annual income, education, land holding, mass media exposure and extension contacts.
\end{abstract}

Keywords: Farmers, Utilization, Mass Media, Socio-economic. 


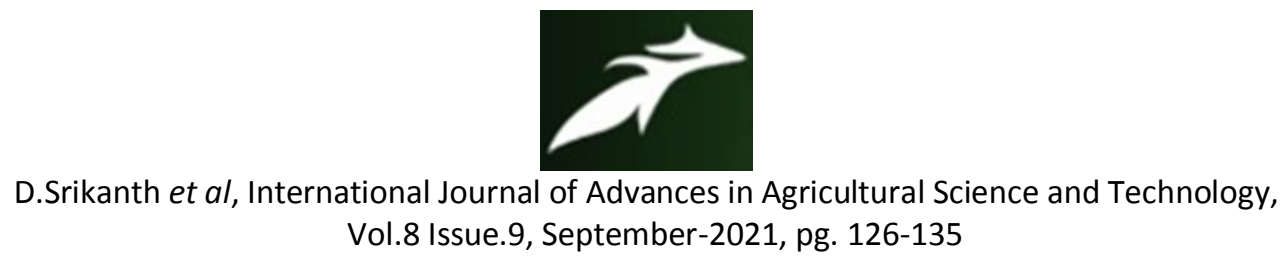

Vol.8 Issue.9, September-2021, pg. 126-135

ISSN: 2348-1358

Impact Factor: 6.057

NAAS Rating: 3.77

\section{INTRODUCTION}

The agricultural growth considerably depends on the communication of information and knowledge which is transferred among farmers the mass media plays an important role in dissemination of agricultural information, the mass media contributes in spreading of information and enables remote areas farmers to make decision about farming activities (Chhachhar, 2012).

Mass media are those channels of communication which can expose large numbers of people to the same information at the same time. They include media which convey information by sound (radio); moving pictures (television, films); and print (posters, newspapers, leaflets). Mass media is one of the power full source of information which disseminates information about health, education, social, political and agricultural development, etc. it categorizes into electronic and print media. The mass media plays very significant role in the agricultural awareness of farmer which ultimately increase the production (Javid, 2017).

\section{Objectives:-}

1. To ascertain the socio-economic profile of the respondents.

2. To analyses the Utilization of Mass Media by the Farmers. 


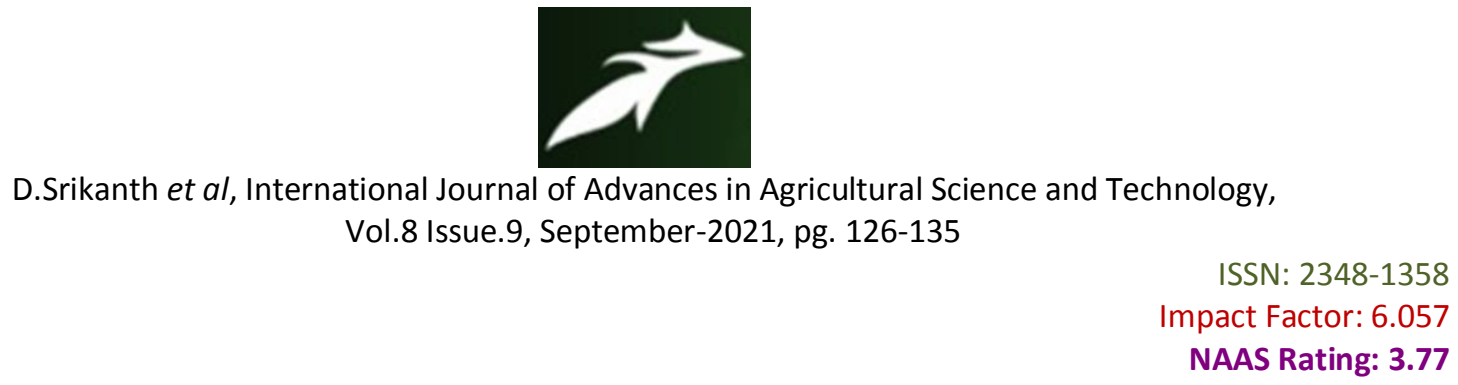

\section{RESEARCH METHODOLOGY}

This section describes the approaches and methods employed for data collection and analysis. The first sub-section of this chapter presents the description of the study area. Then the details of methodology used to conduct the overall study were discussed in subsequent and subsections. Descriptive research design was used for the present study. Descriptive research design is used to describe the characteristics of a population or phenomenon being studies. Mahabubnagar district of Telangana state was selected purposively based on the maximum farmers' availability. There were 15 mandals in out of which Addakal mandal was selected purposively based on the maximum farmers availability in that area, through the help of agricultural officer. There are 14 villages in Addakal mandal out of those which six villages were selected purposively based on the progressive farmers. 120 numbers of farmers were selected for the present study. Randomly 20 number of farmers were selected from 6 villages with the help of village Sarpanch and agriculture supervisor of respective village (VLW) involvement in agriculture and progressive farmers. The Primary data was collected with the help of personal interview technique, pre-tested structured interview schedule designed especially in the light of objectives setup for the study. The Secondary data was collected from library, journals, books, papers and the documents related to the study. The responses to the raw quantitative data coded and stored using Microsoft excel spreadsheet in order to avoid respondent anonymity. They were summarized while qualitative responses were tailed and finally prioritized in order to determine trends and patterns in the data and draw conclusions. It was also describes, analyzed on the spot during data collection to avoid missing of relevant information. 


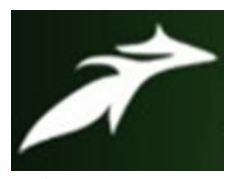

D.Srikanth et al, International Journal of Advances in Agricultural Science and Technology,

Vol.8 Issue.9, September-2021, pg. 126-135

ISSN: 2348-1358

Impact Factor: 6.057

NAAS Rating: $\mathbf{3 . 7 7}$

\section{RESULTS AND DISCUSSION}

Title table -1: Socio-economic profile of the respondent.

\begin{tabular}{|c|c|c|c|c|}
\hline Sl.no & Socio economic $_{I}$ & ofile of the respondent & Frequency & Percentage \\
\hline \multirow{3}{*}{1} & \multirow{3}{*}{ Age } & Low (35 years) & 23 & 19.17 \\
\hline & & Medium (36-55 years) & 67 & 55.83 \\
\hline & & High (Above 55 years) & 30 & 25 \\
\hline \multirow{3}{*}{2} & \multirow{3}{*}{ Family size } & Small (1-4) & 79 & 65.83 \\
\hline & & $\operatorname{Medium}(5-8)$ & 29 & 24.17 \\
\hline & & Large (8above) & 12 & 10.00 \\
\hline \multirow{3}{*}{3} & \multirow{3}{*}{ Annual income } & Low (below 50,000) & 31 & 25.83 \\
\hline & & Medium $(50,000-90,000)$ & 50 & 41.67 \\
\hline & & High (Above 90,000) & 39 & 32.50 \\
\hline \multirow{5}{*}{4} & \multirow{5}{*}{ Education status } & Illiterate & 15 & 12.50 \\
\hline & & Primary & 45 & 37.50 \\
\hline & & Upper Primary & 25 & 20.83 \\
\hline & & Secondary & 15 & 12.50 \\
\hline & & Higher Secondary & 12 & 10.00 \\
\hline \multirow{3}{*}{5} & \multirow{3}{*}{ Land holding } & Low (0-5 acre) & 49 & 40.83 \\
\hline & & Medium (5-10 acre) & 59 & 49.17 \\
\hline & & High( above 10 acre) & 12 & 10.00 \\
\hline \multirow{3}{*}{6} & \multirow{3}{*}{$\begin{array}{l}\text { Mass Media } \\
\text { Exposure }\end{array}$} & Low (10-15) & 27 & 22.50 \\
\hline & & Medium (16-20) & 64 & 53.33 \\
\hline & & High (21-25) & 29 & 24.17 \\
\hline \multirow{3}{*}{7} & \multirow{3}{*}{$\begin{array}{l}\text { Extension } \\
\text { contacts }\end{array}$} & Low (5-8) & 27 & 22.50 \\
\hline & & Medium (9-11) & 63 & 52.50 \\
\hline & & High (12-14) & 30 & 25 \\
\hline
\end{tabular}

From the table-1. The results described as followed:

From the table-1 reveals that majority of respondents belonged to medium age group. This group alone constitutes 55.83per cent of the total sample. This findings was line with the findings of Nazari and Hassan (2011). 


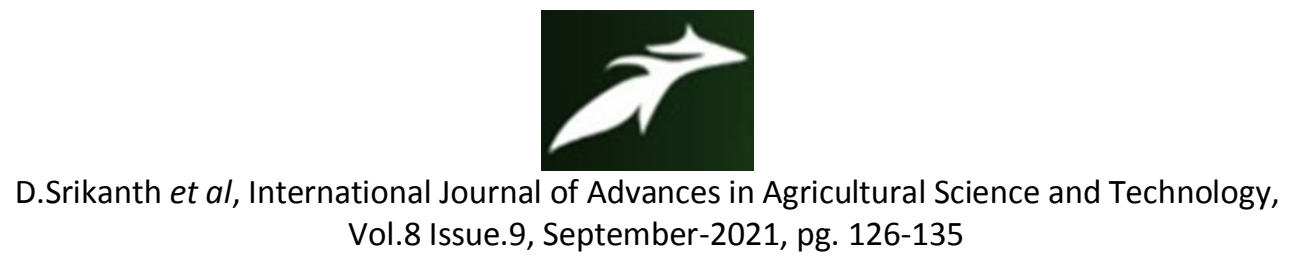

Vol.8 Issue.9, September-2021, pg. 126-135

ISSN: 2348-1358

Impact Factor: 6.057

NAAS Rating: 3.77

It was evident that majority of respondent's belonged to below 4 member family size. This group alone constitutes 65.83 per cent of the total sample. This findings was line with the findings of kafura et al., (2017).

It was observed that majority of respondents belonged to the medium level of Annual Income i.e. 41.67per cent 50,000-90,000. This findings was line with the findings of rathore 2009 .

It was revealed that majority of respondent's belonged to the primary level of education i.e. 37.50per cent. This findings was line with the findings of Panda (2014).

It was evident that majority of the respondents belongs to medium level of land holding i.e. 49.17per cent farmers possessed medium amount of land holding (5-10 acres), this findings was line with the findings of Panda (2014).

It was observed that majority of farmers belonged to the medium level of mass media exposure. This group alone constitutes 53.33per cent of the total sample. This findings was line with the findings of Kumar et al., (2017).

It was revealed that majority of respondents belonged to the medium level of extension contact. This group alone constitutes 52.50per cent of the total sample. This findings was line with the findings of Mangan et al., (2014). 


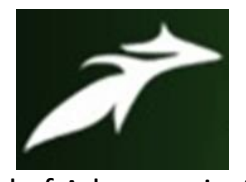

D.Srikanth et al, International Journal of Advances in Agricultural Science and Technology, Vol.8 Issue.9, September-2021, pg. 126-135

ISSN: 2348-1358

Impact Factor: 6.057

NAAS Rating: 3.77

Table-2: Utilization of Mass Media by the Farmers.

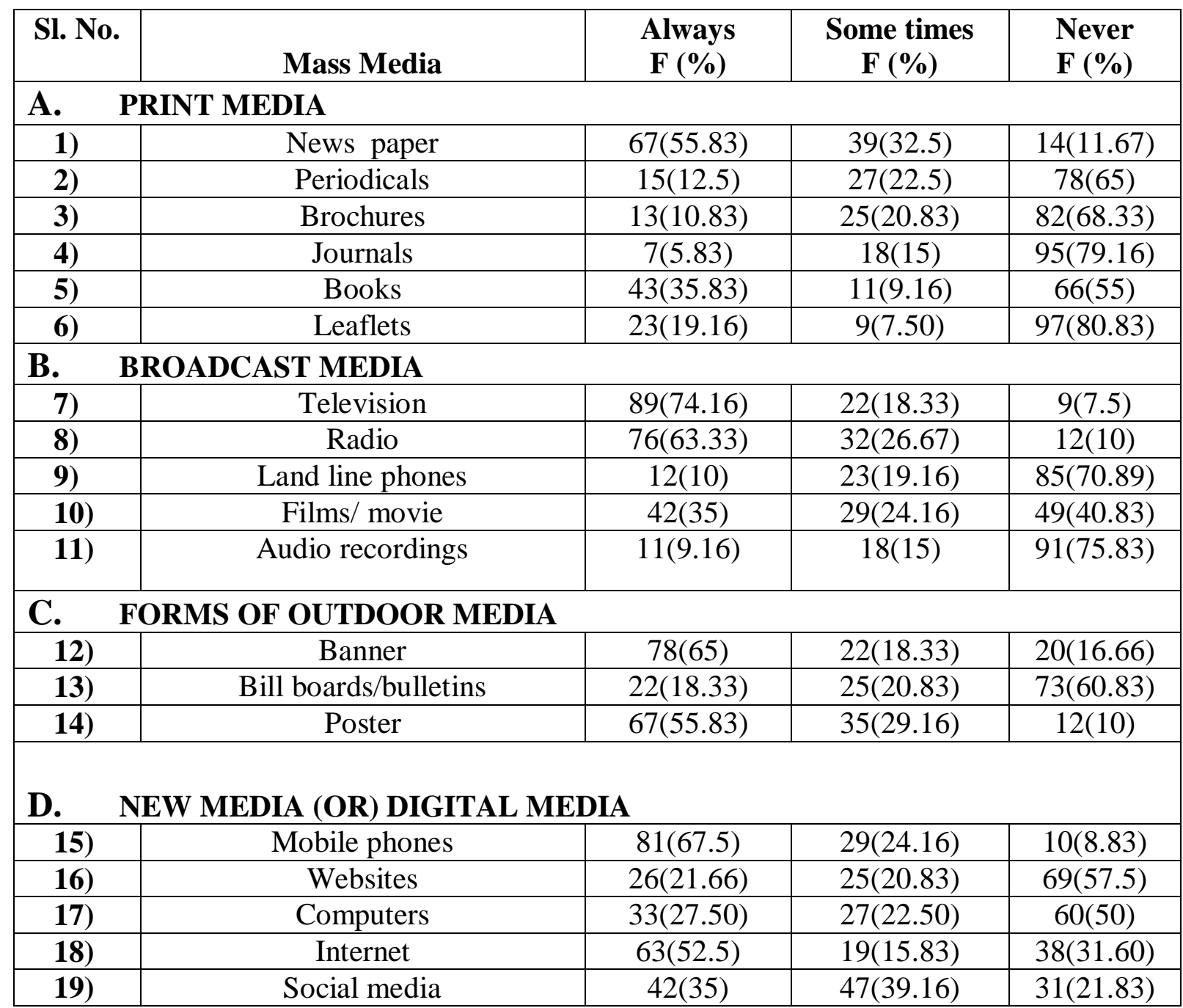




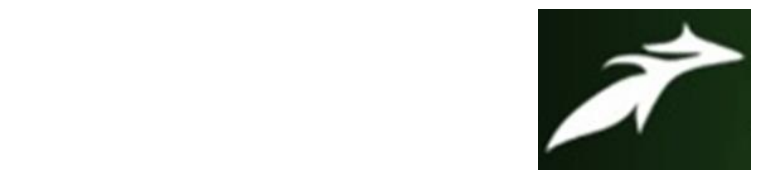

D.Srikanth et al, International Journal of Advances in Agricultural Science and Technology,

Vol.8 Issue.9, September-2021, pg. 126-135

ISSN: $2348-1358$

Impact Factor: 6.057

NAAS Rating: 3.77

\section{From the table- 2: the results depicted as followed:}

From the above table-2 the major findings are 55.83 per cent of farmers are always utilizing newspaper as print media, followed by 65 per cent farmers are never utilizing Periodicals as print media, followed by 68.33 per cent farmers are never utilizing Brochures as a print media, followed by 79.16. 33 per cent farmers are never utilizing journals as a print media, followed by 55 per cent of the respondents are never utilizing books as a print media, followed by 80.83 per cent of the respondents never utilizing leaflets as a print media.74.16 per cent of farmers are always using television as broad caste media, followed by 63.33 per cent of the respondents are always using radio as a broad caste media, followed by 70.89 per cent of the farmers are never using land line phones as a broad caste media, followed by 40.83 percent of the respondents are never using films/movies as a broad caste media, followed by 75.83 per cent of the respondents never using audio recordings as a broad caste media. 65 percent of the respondents are always using banners as an outdoor media followed by 60.83 per cent of the respondents are never using bill board/bulletin as an outdoor media, followed by 55.83 per cent of the respondents are always using posters as an outdoor media. 67.5 per cent of the respondents are always using mobile phones a s a new media/ digital media, followed by 57.5 per cent of the respondents are never using websites as a new media/digital media, followed by 50 per cent of the respondents are never using computers as a new media/digital media, followed by 52.5 per cent of the respondents are always using internet as a new media/digital media, followed by 39.16 per cent of the respondents are sometimes using social media as a new media / digital media. 


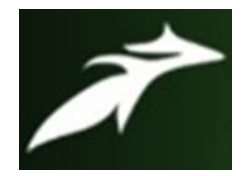

D.Srikanth et al, International Journal of Advances in Agricultural Science and Technology, Vol.8 Issue.9, September-2021, pg. 126-135

ISSN: 2348-1358

Impact Factor: 6.057

NAAS Rating: 3.77

Table 3: Overall distribution of utilization of mass media by the respondents. $n=120$

\begin{tabular}{|c|c|c|c|}
\hline \multirow{2}{*}{ Sl.no. } & Utilization of mass media & \multicolumn{2}{|c|}{ Response } \\
\cline { 3 - 4 } & & Frequency & Percentage \\
\hline $\mathbf{1}$ & Low (19-29) & 22 & 18.33 \\
\hline $\mathbf{2}$ & Medium (30-39) & 35 & 29.17 \\
\hline $\mathbf{3}$ & High (40-49) & 63 & 52.50 \\
\hline & Total & $\mathbf{1 2 0}$ & $\mathbf{1 0 0 . 0 0}$ \\
\hline
\end{tabular}

\section{From the table- 3: the results depicted as followed:}

The data presented in above table- 3 reveals that majority of the respondents belonged to the high level of Utilization of mass media. This group alone constitute 52.50per cent of the total sample, a considerable number of respondents 29.17per cent of the respondents were belongs to the medium level and 18.33per cent respondents were belonged to the low level of utilization of mass media. The above findings were in conformity with. research finding of (Singh 2020.) 


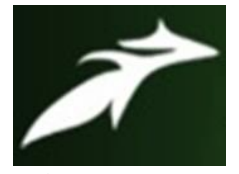

D.Srikanth et al, International Journal of Advances in Agricultural Science and Technology,

Vol.8 Issue.9, September-2021, pg. 126-135

ISSN: 2348-1358

Impact Factor: 6.057

NAAS Rating: 3.77

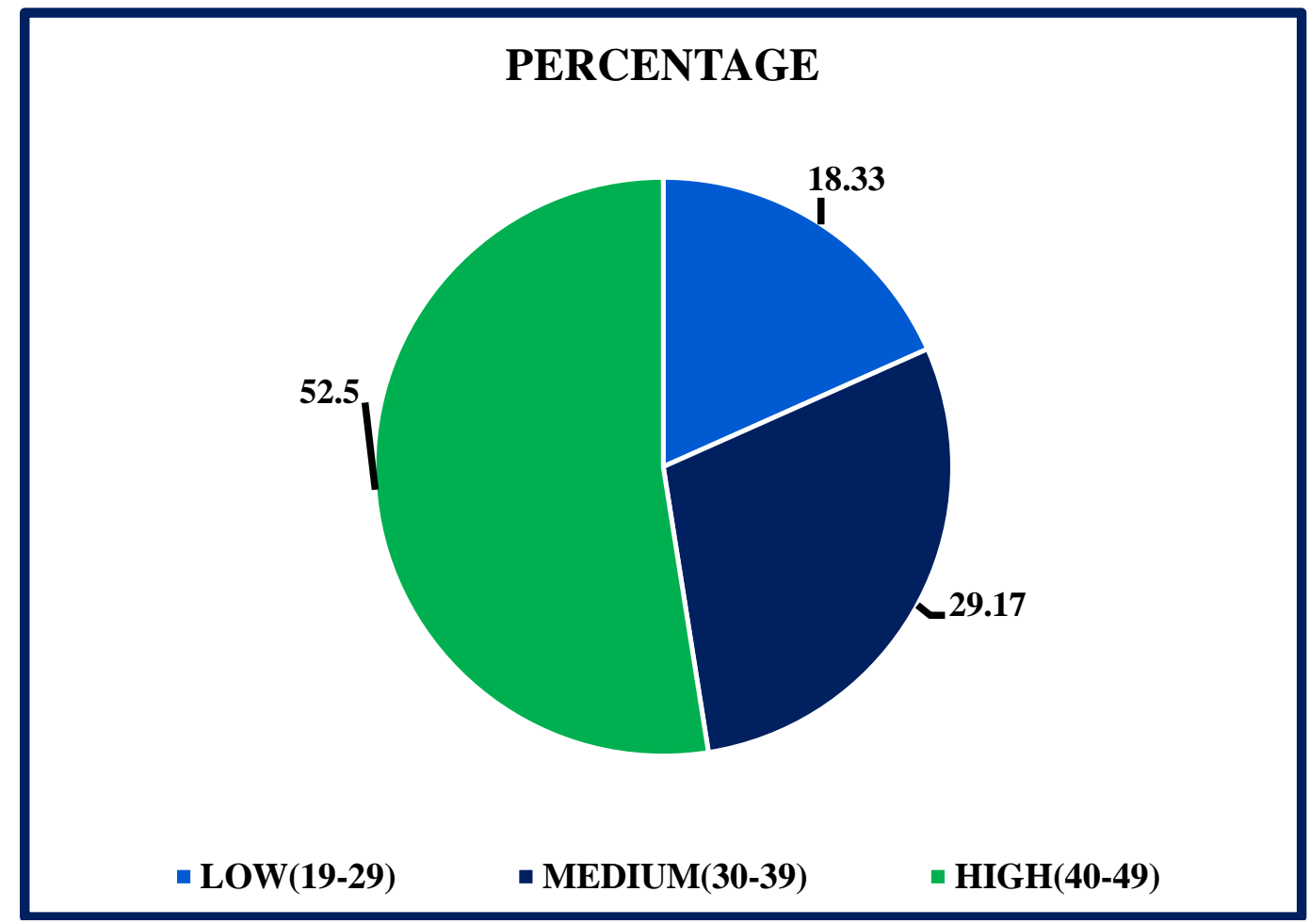

Fig.-1

Table -4 Relationship between independent variable and utilization of mass media by the farmers. $n=120$.

\begin{tabular}{|c|c|c|}
\hline SL No. & Independent Variables & $\mathbf{~} \mathbf{X}^{\mathbf{2}}$ value for utilization of mass media \\
\hline 1 & Age & $21.771^{*}$ \\
\hline 2 & Family size & $67.411^{*}$ \\
\hline 3 & Annual income & $9.822^{*}$ \\
\hline 4 & Education & $40.220^{*}$ \\
\hline 5 & Land holding & $51.075^{*}$ \\
\hline 6 & Mass media exposure & $11.325^{*}$ \\
\hline 7 & Extension contacts & $10.557^{*}$ \\
\hline
\end{tabular}

*chi-square $\left(\mathbf{X}^{\mathbf{2}}\right)$ value at $1 \%$ level of significance at 2 degrees of freedom (9.210).

**chi-square $\left(\mathbf{X}^{2}\right)$ value at $5 \%$ level of significance at 2 degrees of freedom (5.991). 


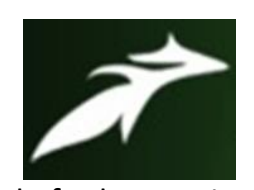

D.Srikanth et al, International Journal of Advances in Agricultural Science and Technology,

Vol.8 Issue.9, September-2021, pg. 126-135

ISSN: 2348-1358

Impact Factor: 6.057

NAAS Rating: 3.77

\section{From the table- 4: the results depicted as followed:}

Statistical analysis about the relationship between age, family size, annual income, education, land holding, mass media exposure and extension contacts with utilization of mass media shows that calculated value of $\mathrm{X}^{2}$ is $21.771,67.411,9.822,40.220,51.075,11.325$ and 10.557 respectively higher than the table value of $X^{2}(9.210)$ at $1 \%$ level of significance at 2 degrees of freedom. Hence there is a significant relationship between age, family size, annual income, education, land holding, mass media exposure and extension contacts with utilization of mass media.

\section{CONCLUSION}

It was concluded that the socio-economic status of the respondents constitute medium level. It was observed that majority of the respondents belonged to the high level of Utilization of mass media. There was a positive \& significant relationship between utilization of mass media with independent variables like age, family size, annual income, education, land holding, mass media exposure and extension contacts.

\section{REFERENCES}

[1]. Chhachhar, A. R., Hassan, Osman, M. N., \& Omar, S. Z. (2012). The roles of Television in agriculture development of Sindh, Pakistan. Human Communication. A Publication of the Pacific and Asian Communication association. 15(1), $1-11$.

[2]. Javid, U. (2017) Role of Mass Media in Promoting Agricultural Information among Farmers of District Nankana. Pak. J. Agri. Sci. 54(3), 711-725.

[3]. Kafura, R.A; Afrad, M.D; Prodhan, F.A. and Chakra borty, D.B. (2016) Use of ICT as Extension Tool by the Farmers of Gazipur District in Bangladesh. Indian Res. J. Ext. Edu.16 (2).

[4]. Khan, S. Hammadur, M. R. and Uddin, M. N. (2017) Effectiveness of selected mass media in agricultural technology transfer to the farmers of Bangladesh. Res. Agric. Livest. Fish. 4(1).

[5]. Kumar, R; Hudda, R.S; Chahal, P. and Yadav, K. (2017) Availability of Information and Communication Technologies (ITCs) tools usages by Farmers in Haryana. Int. J. Pure App. Biosci., 5(3):648-653, ISSN: $2320-7051$.

[6]. Magnan, N; David, J; Spielman, T;Lybbert, J. and Gulati, K. (2014) Social networks and Indian farmers demand for agricultural custom hire services. USAID, CSISA (The cereal system initiative for South Asia), 1 - 4.

[7]. Nazari, M. R. and Hassan, M. S. B. H. (2011) the role of television in the enhancement of farmers' agricultural knowledge. African Journal of Agricultural Research. 6(4), 931-936.

[8]. Nwalieji, H. U. Ezeakunne, C. C. Enwelu, I. A. Okeke, M. N. Udemezue, J. C. and Uzuegbunam, C. O. (2019) Mass Media Utilization by Poultry Farmers in Anambra State, Nigeria. Journal of Agricultural. 23 (2).

[9]. Panda, C. K. (2014) Information Sources and Technology Adoption by Farmers: An Empirical Study in Mohanpur Block, West Tripura. International J. of Exten. Edu. Vol. 10: 80-87.

[10].Singh, A. (2020) Study on effect of mass media for changing farmers socio-economic status in Varanasi district of Uttar Pradesh Thesis M.Sc. Acharya Narendra Deva University of Agriculture and Technology. 